\title{
Hyperoleon masquerading as leukocoria
}

\author{
Rahul Kumar Bafna (ㄷ), Karthikeyan Mahalingam 주, Bhavika Bansal
}

Ophthalmology, Dr Rajendra Prasad Centre for Ophthalmic Sciences, All India Institute of Medical Sciences, New Delhi, India

\section{Correspondence to}

Dr Karthikeyan Mahalingam; kalingachit@gmail.com

RKB and KM are joint first authors.

Accepted 7 September 2021

\section{DESCRIPTION}

An 8-year-old boy presented with white reflex in the right eye (RE) for 6 months. RE visual acuity was perception of light present with projection of rays accurate in all quadrants. Slit-lamp examination revealed numerous emulsified silicone oil droplets (figure 1) filling the anterior chamber completely, obscuring the view of posterior segment. The patient had a history of multiple vitreoretinal surgeries for retinal detachment. The last vitreoretinal surgery with silicone oil injection was done 2 years ago and the patient was lost to follow-up (so timely removal of silicone oil could not be done). Intraocular pressure (IOP) was $48 \mathrm{~mm}$ $\mathrm{Hg}$ on maximum tolerable glaucoma medications. RE ultrasonography revealed an oil-filled eye with attached retina. RE silicone oil removal was done and postoperative visual acuity was hand movements close to face with projection of rays accurate in all quadrants, IOP was $12 \mathrm{~mm} \mathrm{Hg}$. There was corneal oedema postoperatively which improved over time for 2 weeks. The retina was attached at 3-month follow-up. Emulsification of silicone oil is a known complication after its use in vitreoretinal surgery. ${ }^{1}$ It usually appears as oil droplets superiorly in anterior chamber or in angles during gonioscopy. ${ }^{2}$ There is no report of hyperoleon (emulsified silicone oil) completely filling the anterior chamber masquerading as leukocoria. Causes of leukocoria at this age group could be Coats' disease, congenital cataract, retinoblastoma (late onset), astrocytic hamartoma, ocular toxocariasis, chorioretinal coloboma, healed

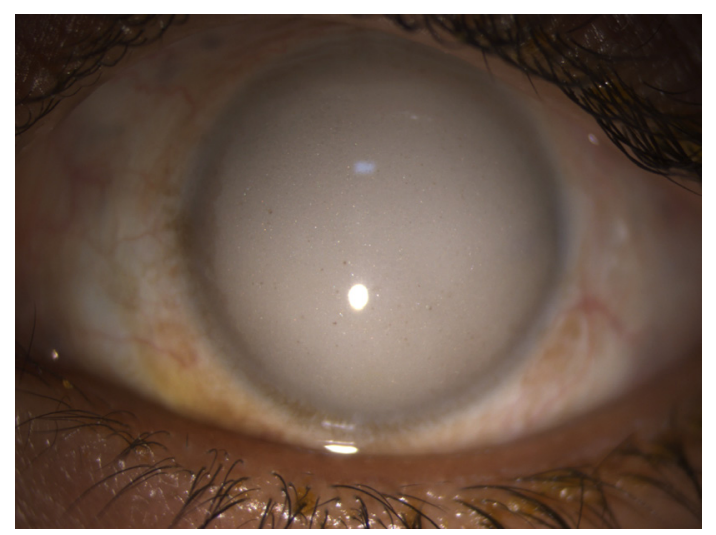

Figure 1 Hyperoleon in anterior chamber. keratitis, retinal detachment, endophthalmitis, etc. ${ }^{3}$ There is a stronger correlation with emulsification and longer duration of silicone oil stay. ${ }^{4} \mathrm{~A}$ higher number of large-diameter emulsified silicone oil droplets were found in younger patients compared with older individuals. ${ }^{5}$ Timely removal of silicone oil is necessary to prevent complications like emulsification, secondary glaucoma and keratopathy. ${ }^{6}$

\section{Learning points}

Hyperoleon completely filling the anterior chamber can masquerade as leukocoria.

- It can cause intractable secondary glaucoma and corneal decompensation.

- Timely removal of silicone oil is necessary to prevent its complications.

Contributors KM was involved in data acquisition, manuscript drafting, preparation, and intellectual input, and approved the final manuscript. RKB and BB were involved in data acquisition and intellectual input, and approved the final manuscript.

Funding The authors have not declared a specific grant for this research from any funding agency in the public, commercial or not-for-profit sectors.

\section{Competing interests None declared.}

Patient consent for publication Obtained.

Provenance and peer review Not commissioned; externally peer reviewed.

\section{ORCID iDs}

Rahul Kumar Bafna http://orcid.org/0000-0002-6795-0508 Karthikeyan Mahalingam http://orcid.org/0000-0003-4396-825X

\section{REFERENCES}

1 Toklu Y, Cakmak HB, Ergun SB, et al. Time course of silicone oil emulsification. Retina 2012;32:2039-44.

2 Tripathy K, Sharma YR. Inverted hypopyon in the eye. BMJ Case Rep 2016;2016:bcr2016214638.

3 Balmer A, Munier F. Differential diagnosis of leukocoria and strabismus, first presenting signs of retinoblastoma. Clin Ophthalmol 2007;1:431-9.

$4 \mathrm{Ni}$ Y, Fang $\mathrm{H}$, Zhang $\mathrm{X}$, et al. Analysis of the causative factors related to earlier emulsification of silicone oil. Int J Ophthalmol 2019;12:517-9.

5 Yu J, Zong Y, Jiang C, et al. Silicone oil emulsification after vitrectomy for rhegmatogenous retinal detachment. J Ophthalmol 2020;2020:1-6.

6 Miller JB, Papakostas TD, Vavvas DG. Complications of emulsified silicone oil after retinal detachment repair. Semin Ophthalmol 2014;29:312-8. 
Copyright 2021 BMJ Publishing Group. All rights reserved. For permission to reuse any of this content visit https://www.bmj.com/company/products-services/rights-and-licensing/permissions/

BMJ Case Report Fellows may re-use this article for personal use and teaching without any further permission.

Become a Fellow of BMJ Case Reports today and you can:

- Submit as many cases as you like

Enjoy fast sympathetic peer review and rapid publication of accepted articles

Access all the published articles

Re-use any of the published material for personal use and teaching without further permission

Customer Service

If you have any further queries about your subscription, please contact our customer services team on +44 (0) 2071111105 or via email at support@bmj.com.

Visit casereports.bmj.com for more articles like this and to become a Fellow 